\title{
Tax Reform for a Fairer, More Vibrant Economy
}

\author{
Lok Sang Ho*, Tianle Zhang* \\ Lingnan University, Hong Kong, China \\ Email: "Lsho@Ln.edu.hk, Tianlezhang@Ln.edu.hk
}

Received 20 June 2016; accepted 25 July 2016; published 28 July 2016

Copyright (C) 2016 by authors and Scientific Research Publishing Inc.

This work is licensed under the Creative Commons Attribution International License (CC BY). http://creativecommons.org/licenses/by/4.0/

(c) (i) Open Access

\begin{abstract}
The paper reviews the recent literature on tax reform, and recommends abolishing the profits tax and treating personal incomes from all sources as taxable, including capital gains and dividends. Abolition of the profits tax will vastly improve the investment environment and eliminate wasteful distortions. We also offer an intermediate "gradualist" approach involving halving the profit tax rate and taxing half of dividends and capital gains. We augmented a model proposed by Chetty and Saez [1] to incorporate the effects of manager effort for investment and showed the strong adverse effect of the profit tax on investment. Given that successive increments in total personal incomes from all sources are typically characterized by increasing intensity in economic rent, a progressive tax structure with high marginal tax rates at the top and wide tax bands is not only more equitable, but can be justified on efficiency grounds.
\end{abstract}

\section{Keywords}

Tax Reform, Economic Rent, Rent Intensity, Progressivity, Efficiency

\section{Introduction}

In a recent article in Financial Times, Lawrence Summers (2012) [2] raised concerns over how to raise revenue, fairness, avoiding excessive complexity, and the adverse effects of such complex tax rules on the economy. ${ }^{1}$ As events unfold showing the prevalence of tax inversion and tax avoidance amid a dearth of investment and discontent over the rising inequality, the need for a simpler, fairer, and more pro-growth tax system has become apparent.

In a highly globalized environment, with tax arbitrage, tax havens, and developments in information technol-

${ }^{*}$ Corresponding authors.

“"How to fix costly and unjust US tax system” Financial Times, December 16, 2012. 
ogy making transactions on the internet increasingly popular, tax revenues from profits taxes are dwindling even without the various allowances introduced by politicians favoring particular industries and particular activities. ${ }^{2}$ Raising revenues from the profits tax has become an increasingly daunting task, while tax evasion is distorting activities and causing deadweight loss for society. In order not to lose the tax base altogether, and in order to boost economic activities, most countries have been aggressively cutting the tax rate. For example, despite proclamation to adhere to fiscal austerity, UK Finance Minister George Osborne cut the corporation tax rate another percentage point to 20 percent effective April 1 2015, and promised further cuts, down from 28 percent when the coalition government came to power. While profit tax rates keep falling, penalties for tax avoidance by big corporations have become quite rare. Indeed, David Gauke, the UK tax minister, "is able to declare without a hint of a blush" that such leniency "is as important to tax competitiveness as the tax we set". ${ }^{3}$

Citing OECD studies, the report Paying Taxes 2014: the Global Pictures, observed that the "profits tax is the least growth friendly type of tax ..."4 If the profits tax hurts investment, replacing it with alternative taxes that focus more on "rent-intensive" incomes should spark off an increase in investment and employment opportunities. This paper attempts to tackle the question of how to do this.

Section 2 reviews some recent evidence that suggests abolishing the corporate profit tax will improve both efficiency and equity, and removes the objection against taxing dividends on account of double taxation. While there is an argument that a tax on dividend can undermine the quality of investment, there is no evidence from total factor productivity data that the American economy had benefited from President Bush's generous dividend tax cut, which had cost an estimated $\$ 100$ billion revenue from 2003-2008. On the other hand, Desai and Goolsbee [3] noted that while this dividend cut had little, if any, impact on investment, the partial expensing of equipment provisions, at a revenue cost of approximately $\$ 130$ billion from 2002-2003, which translates into a profit tax cut, did have a small positive effect on investment.

Section 3 makes the observation that for each person, as personal incomes from all sources go up, typically the percentage of economic rent in each increment in income rises. Some evidence to this effect is presented. From this observation it is suggested that raising the top marginal tax rates need not affect incentives on effort, provided that they apply to increases in income that are on top of already very high incomes. Since people with higher incomes (from all sources) tend to earn proportionately more economic rent than people with lower incomes, widening tax bands and increasing progressivity will have positive effects on working incentives for workers and little behavioral effects on rent-earners. Section 4 presents a tax calculation for revising tax bands and tax rates and examines implications on behavior and on efficiency, and possible needs for tax harmonization. Section 5 considers the question of progressive income tax versus progressive consumption tax, and whether taxing consumption is superior to taxing incomes. Section 6 concludes the paper, making some additional remarks on taxes on environmental disruption and on diamond goods.

\section{Eliminating the Corporate Profit Tax?}

The corporate profit tax has long been known as an important consideration for firms' locational decisions. ${ }^{5}$ Devereaux [4] concluded from his survey of empirical works and his own analysis that the effective average (profit) tax rates tend to play a significant role in discrete location choices, even though the effects of marginal tax rates are rather minor. Hassett and Hubbard [5] suggested that replacing the corporate income tax with a consumption tax would lead to about a $10 \%$ increase in equipment investment, through reducing the user cost of capital. More recently, a cross-country study found corporate taxes to have large and significant adverse effects on corporate investment and entrepreneurship (Djankov, et al. [6]). Finally, Fehr and his co-authors simulated the elimination of the US corporate profit tax [7] and found that the abolition of the profit tax "produces rapid and dramatic increases in the model's level of U.S. investment, output, and real wages, making the tax cut

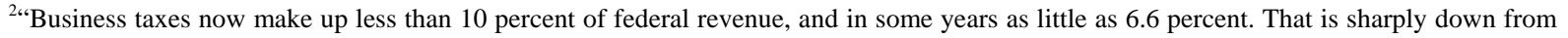
the years after World War II, when about 30 percent of federal revenue came from corporate taxes.” See David Gelles, Businesses Are Winning Cat-and-Mouse Tax Game, New York Times, August 28, 2014.

${ }^{3}$ The penalties levied by HMRC against large companies had dropped to 0.01 per cent of the tax they under-declared on their tax returns. See the Book Review by Jonathan Ford in Financial Times, March 22, 2013. World Bank Group and PWC(2013): Paying Taxes 2014: The Global Picture, November 19, 2013. http://www.doingbusiness.org/reports/thematic-reports/paying-taxes

${ }^{4}$ World Bank Group and PWC(2013): Paying Taxes 2014: The Global Picture, November 19, 2013.

http://www.doingbusiness.org/reports/thematic-reports/paying-taxes

5“"The results of Area Development's 2009 Corporate Survey illustrated the importance of taxation when companies select locations for new operations." http://www.areadevelopment.com/taxesIncentives/sept2010/taxation-decision-location-selection3991.shtml
} 
self-financing to a significant extent.” These authors argued that the resulting investment boom and thus higher capital per worker would mean higher labor productivity and higher real wages. Their simulation results show that even if taxes on wages were used to finance the abolition of the corporate profit tax, enhanced investment in the US would still raise the real wages of unskilled workers by 12 percent and those of skilled workers by 13 percent (p. 2), resulting in higher take-home pays for workers.

Perhaps one reason why the profit tax has not been scrapped is the apparent lack of consistency in the results of a profit tax reduction on investment. Baccini et al. [8] using a quasi-experimental design assessed the impacts of different profit tax policies on various Russian regions. Those regions were granted autonomy to reduce corporate profit tax in 2003. The authors found that, on average, relative to the absence of tax cuts, nondiscriminatory tax cuts on direct investment profit do increase FDI, whereas discretionary tax cuts on selected government-sanctioned investment projects do not. Sometimes, some investments are just not viable, perhaps due to the nature of the industry, or perhaps due to the overall business environment of the locality. Eliminating the profit tax altogether is a non-discriminatory tax relief and is certainly more efficient than administratively picking on specific locations or specific projects for relief.

Still, many people will object to eliminating the profit tax. First of all, the profit tax is a significant source of fiscal revenue. Secondly, profit is not always the result of good management or good business decisions, and can sometimes be fortuitous. Moreover, corporations are routinely seen to be the most appropriate targets to levy a tax on because they are perceived to be powerful and exploitative. Taxes on corporations are politically more palatable than taxes on individuals. Following the principle of gradualist reform, ${ }^{6}$ it is proposed that profit tax rates be halved, while half of distributed dividends are subject to tax. It can be proven that there will be no double taxation under this arrangement. ${ }^{7}$ This taxable dividend income should be taxed according to the marginal tax rates applicable to the individual.

Halving the profits tax rate and at the same time taxing half of dividends and capital gains at progressively higher marginal tax rates as applicable to the individual should allow the government to recoup most if not all of the lost revenues due to halving the profit tax.

Halving the profit tax on investment will significantly spur spending on fixed capital formation and R\&D, and benefit employment creation and raising incomes for the masses.

With a significantly lower profit tax, the tax savings will be capitalized into stock values, leading to a onetime jump in stock prices. If the investment climate improves, and if the effective tax on wages for the majority of workers is reduced through widening the tax bands, the purchasing power of the masses will rise. Higher demand should boost sales and profits, and capital gains will be bigger over the longer term. Treating half of capital gains and dividends the same as other personal incomes will generally lead to higher effective tax rates on those with very high incomes, even after allowing for an exemption of inflationary gains.

On the subject of compliance and collection, since shares are registered under owners' names or nominees, and nominees have an incentive to report incomes that accrue to the true owners, tax evasion from dividend incomes is almost impossible. ${ }^{8}$ Dividends can of course be paid to companies. But if owners of companies and their executives cannot arbitrarily charge their consumption expenditures as business expenses, ${ }^{9}$ then the dividends collected will either feed investment or be distributed to individuals. In the former case, not taxing them contributes to growth. In the latter case they will be taxed as personal incomes without distorting investment.

Given today's technology, it should be simple for the tax authorities to track down dividend payouts to individuals and on capital gains. The tax authorities should have no difficulty in generating a consolidated dividend income statement for each taxpayer. Admittedly, not all countries are technologically ready to do this. But where the technology is available the reform should greatly improve efficiency and simplify compliance and collection.

In America, capital gains are presently taxed at different rates depending on whether the gains have been achieved within or beyond one year of holding of the asset. The tax rate on long-term gains was reduced in 1997 from $28 \%$ to $20 \%$ and further from $20 \%$ to $15 \%$ in 2003 . For those whose effective marginal tax rate is less than $15 \%$, the tax rate on capital gains was cut from 10\% to 5\%. The American Enterprise Institute has always argued for repealing the capital gains tax, in part on the ground that it represents double tax, which makes some sense if

\footnotetext{
${ }^{6}$ See Shangjin Wei (1997) [9].

${ }^{7}$ President George W. Bush in 2003 proposed the elimination of the U.S. dividend tax on double taxation grounds. Currently dividends are taxed at favourable rates.

${ }^{8}$ Richard Bird advised that this may not be the case in developing countries.

${ }^{9}$ One way of doing this is to cap entertainment expenses as a percentage of pretax profits.
} 
profits are already taxed, and in part on the ground that abolishing the tax would stimulate economic growth. ${ }^{10}$ But halving the profits tax and taxing only half of capital gains and dividends will directly stimulate economic growth, and would render the double tax argument against the capital gains tax invalid. Given that taxes are largely to finance for public goods that benefit the residents of a country concerned while a firm today is more internationally mobile, deemphasizing taxes on profits and emphasizing taxes on dividends and capital gains that go to individuals is also more consistent with the benefit principle of taxation.

Capital gains could, admittedly, be illusory, as when capital gains reflect inflation. To avoid taxing illusory capital gains, we need only offer for each asset an annual inflationary allowance. Making such an allowance is not at all complicated, since the Consumer Price Index is available monthly and, unlike national income accounting statistics, price indices are seldom revised. All that needs to be done is to work out the inflation rate between the time an asset is acquired and the time that asset is disposed. If it is A\% then only gains beyond $\mathrm{A} \%$ is taxable.

One might argue that, if capital gains are taxable, shouldn't capital losses be shared by the government? While it does make sense to allow capital losses to offset gains so as to reduce the tax burden, making the government share losses is problematic, as this may lead to reckless decisions that count on the government to share losses. On the other hand, capital losses can be allowed to be carried forward to offset future gains and thus future tax liabilities.

A recent article by Chetty and Saez [1] presented an agency model to argue that taxing dividend payouts is worse than taxing profit in terms of managerial incentives. If the manager is given shares to motivate him to do a good job because monitoring is costly and may not be effective, a tax on dividends obviously will reduce those incentives, and he may rather spend on some pet project of his that yields personal satisfaction rather than profits. According to their model, between a tax on dividends and a tax on profits, a tax on dividends more directly hits managerial incentives and is therefore more damaging to efficiency. However, by slightly amending the model, and adding the reasonable assumption that investment is not just putting money where there is opportunity but also putting effort, and that the cost of that effort increases with the size of the investment, taxing profits is tantamount to taxing effort and can be shown to have a much bigger negative effect on investment than is shown in Chetty and Saez [1]. A formal demonstration is available in the Appendix. Moreover, if the tax structure is progressive, and the manager's share of dividends are modest, the tax on dividends may have relatively little effects on investment incentives.

Finally, an examination of a utilization-adjusted TFP time series, which is available thanks to work by John Fernald [10] of the Federal Reserve Bank of San Francisco, ${ }^{11}$ shows that, notwithstanding President Bush's generous dividend tax cut in 2003, the growth rate in total factor productivity had fallen since 2008, from $1.39 \%$ prior to the tax cut to $0.55 \%$ in the years after 2003 (Figure 1). Since Desai and Goolsbee [3] had concluded that

\section{Utilization-adjusted TPF}

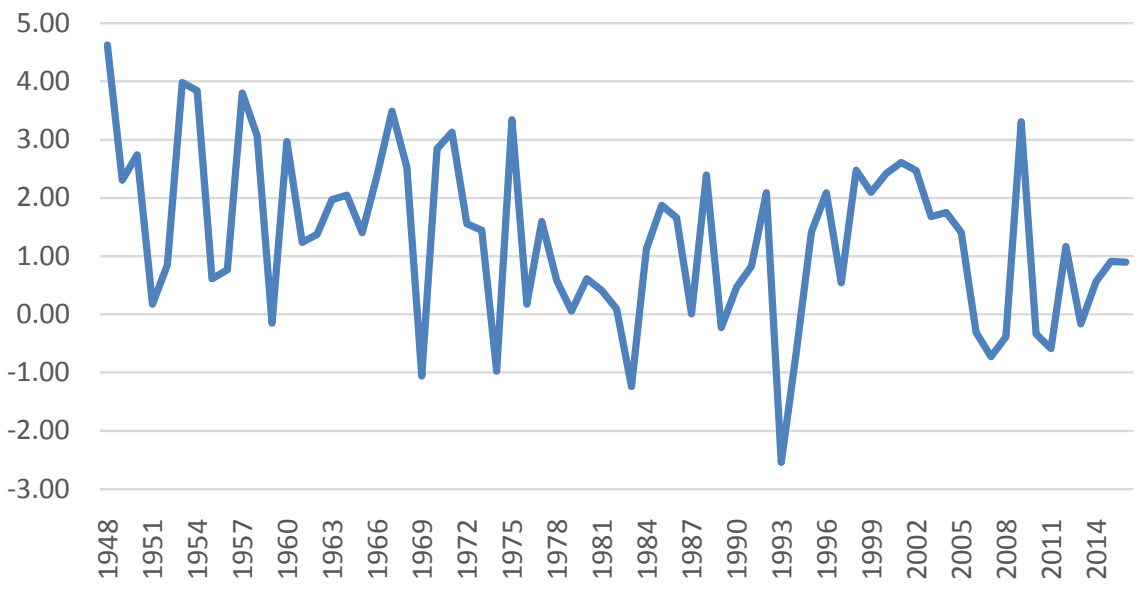

Figure 1. Utilization-adjusted TFP. Source: Supplement to fernald [10]. http://www.frbsf.org/economic-research/economists/john-fernald/.

\footnotetext{
${ }^{10}$ See: http://www.american.com/archive/2009/august/capital-gains-tax-an-argument-for-repeal

${ }^{11}$ See: http://www.frbsf.org/economic-research/files/wp12-19bk.pdf
} 
"the dividend tax cut, while having a high revenue cost, had minimal, if any, impact on marginal investment incentives," and that various studies had pointed to the failure of the Bush dividend tax cut, eliminating the profit tax altogether while counting dividends and realized inflation-adjusted capital gains as personal incomes appear advisable [11].

\section{Taxing Economic Rents through a Progressive Personal Income Tax}

Pure economic rents are by definition the excess earnings over all relevant opportunity costs of a factor of production. The owner of a factor who could put it in a use that is earning economic rent will not withdraw it from that use upon the rent's being taxed, as long as after-tax earnings remain higher than the opportunity cost or "transfer earnings."

In general, if we rank people's personal incomes from all sources, as we observe such incomes from the lowest-earning individual to the highest-earning one, we generally observe that the "rent intensity" of incomes increases with income. Personal incomes comprise wages and salaries, bonuses, rental incomes from properties and assets, dividends, gifts, and realized capital gains. Unskilled workers who sell brute labor earn virtually no economic rent at all. Higher pays reflect compensation for the degree of unpleasantness or risk involved. As we move to the semi-skilled range, incomes are higher, and the compensation reflects a premium that the skill commands. As we move further to the high-skilled range, the skill premium rises rapidly. Two recent studies ([12] [13]) have shown that the elasticity of supply is much higher for low-income wage earners than for highincome wage earners, which is consistent with the conjecture that high skill brings economic rent. Skilled workers whose skills are in short supply in the face of strong demand earn "quasi rent." Supply of labor, particularly on the extensive margin (i.e., participation), tends to be more insensitive to marginal changes in take-home pay because higher tax rates largely only reduce rents, having less influence on incentives.

Moreover, for a given individual, at higher levels of incomes, various sources of non-labour income kick in. From this, it follows that a tax structure with low marginal tax rates applying to taxpayers whose incomes are in the low rent intensity range, and higher marginal tax rates on those whose incomes are in the high rent intensity range, the overall incentive to work will increase, while distortions will be reduced. ${ }^{12}$

It may be submitted that the personal economic rents that some people are enjoying can often be traced to their past effort. For example, author of the Harry Potter series J. R. Rowling and the Korean singer and entertainer Psy, who made history with his Gangnam Style video shattering all download/viewing records, had made a huge effort and had both endured many setbacks before becoming famous. All the superstars that we can name got their status with hard work, and they will continue to keep very high disposable incomes which will be protected by the wide tax bands, even though they will also pay at much higher marginal tax rates under the proposed reforms. Their very high incomes today are certainly not due to their effort alone, but are also a result of modern technology and globalization. ${ }^{13}$ Because of the huge divide between those "making it" and those "not making it" it is unlikely that taxing this economic rent at higher marginal tax rates that go up to $50 \%$ and even beyond ${ }^{14}$ will diminish the effort of would-be superstars, since the reality is that only a handful of those who try very hard will in the end make it to stardom, and "transfer earnings" - what can be earned in the best alternative pursuits, are so much lower than the incomes of superstars. ${ }^{15}$ In addition, while the expected incomes of becoming a superstar may be significantly lower under our proposal, the expected utility (which should be the relevant variable) should be virtually unchanged. It does not make much a difference whether one becomes a superstar with $\$ 10$ billion or $\$ 5$ billion net worth after tax. At such levels of wealth, the marginal utility of wealth is negligible; it is the non-pecuniary returns of success that count.

\section{Tax Calculations Using the 2015 and an Alternative Income Tax Structure}

Table 1 presents the tax calculations for US residents in different income brackets under the 2015 tax structure

\footnotetext{
${ }^{12}$ Let $x$ be income, and actual income be $x^{*}$. Let $f$ be the \% of marginal income that is rent. The "rent intensity ratio" R at any income level $x^{*}$ equals: $\int_{0}^{x^{*}} f(x) \mathrm{d} x / x^{*}$. Given the reasonable assumption that $\mathrm{f}$ is an increasing function of $x$, it is clear the $\mathrm{R}$ also increases with $x^{*}$.

${ }^{13}$ See Rosen [14].

${ }^{14}$ There is of course the fear that a very high marginal rate on the super-rich may lead to his emigration to a country of lower taxes. But if the higher tax paid is in exchange for greater protection under the rule of law and a well governed country with less pollution and lower crime rate, this fear is likely to be exaggerated.

${ }^{15}$ See also Rosen [14], Borghans and Groot [15], and Hamlen, et al. [16].
} 
Table 1. Tax calculations for an individual under old and proposed tax structure; 2015 Personal exemption $=\$ 6300$.

\begin{tabular}{|c|c|c|c|c|c|c|c|c|c|c|c|}
\hline & \multirow{2}{*}{$\begin{array}{c}\text { Gross } \\
\text { Income }\end{array}$} & Taxable & $\begin{array}{c}\text { to } \\
9225\end{array}$ & $\begin{array}{c}\text { to } \\
37,450\end{array}$ & $\begin{array}{c}\text { to } \\
90,750\end{array}$ & $\begin{array}{c}\text { to } \\
189,300\end{array}$ & $\begin{array}{c}\text { to } \\
411,500\end{array}$ & $\begin{array}{c}\text { to } \\
413,200\end{array}$ & $413,201+$ & \multirow[t]{2}{*}{ Total } & \multirow{2}{*}{$\begin{array}{c}\text { Effective } \\
\text { Tax } \\
\text { Rate }\end{array}$} \\
\hline & & Income & $10 \%$ & $15 \%$ & $25 \%$ & $28 \%$ & $33 \%$ & $35 \%$ & $39.60 \%$ & & \\
\hline $\begin{array}{c}25 \\
\text { percentile }\end{array}$ & 12,650 & 6350 & 635 & & & & & & & 635 & 5 \\
\hline $\begin{array}{c}50 \\
\text { percentile }\end{array}$ & 26,500 & 20,200 & 922.5 & 1646.25 & & & & & & 2568.75 & 9.7 \\
\hline $\begin{array}{c}75 \\
\text { percentile }\end{array}$ & 49,800 & 43,500 & 922.5 & 1646.25 & 1512.5 & & & & & 4081.25 & 8.2 \\
\hline $\begin{array}{c}90 \\
\text { percentile }\end{array}$ & 83,000 & 76,700 & 922.5 & 1646.25 & 9812.5 & & & & & $12,381.3$ & 14.9 \\
\hline $\begin{array}{c}95 \\
\text { percentile }\end{array}$ & 112,500 & 106,200 & 922.5 & 1646.25 & 13,325 & 4326 & & & & $20,219.8$ & 18 \\
\hline $\begin{array}{c}99 \\
\text { percentile }\end{array}$ & 210,000 & 203,700 & 922.5 & 1646.25 & 13,325 & 27,594 & 5040 & & & $48,527.8$ & 23.1 \\
\hline $\begin{array}{c}99.5 \\
\text { percentile }\end{array}$ & 450,000 & 443,700 & 922.5 & 1646.25 & 13,325 & 27,594 & 77,770 & 595 & 12,078 & 133,931 & 29.8 \\
\hline Tор 0.2\% & $5,000,000$ & 4,993,700 & 922.5 & 1646.25 & 13,325 & 27,594 & 77,770 & 11,270 & $1,813,878$ & $1,946,406$ & 38.9 \\
\hline \multicolumn{12}{|c|}{ New Tax Calculations under Proposed Tax-Band Widening \& Rate Changes; Revised Personal Exemption = \$20000 } \\
\hline & \multirow{2}{*}{ Gross Income } & Taxable & to 10,000 & to 40,000 & to 80,000 & to 150,000 & to 300,000 & to 400,000 & $00400,000+$ & \multirow{2}{*}{ Total } & Change \\
\hline & & Income & $8 \%$ & $15 \%$ & $25 \%$ & $35 \%$ & $40 \%$ & $45 \%$ & $50 \%$ & & $\%$ \\
\hline $\begin{array}{c}25 \\
\text { percentile }\end{array}$ & 12,650 & 0 & & & & & & & & 0 & $\begin{array}{c}\text { From } \\
\text { positive } \\
\text { to nil }\end{array}$ \\
\hline $\begin{array}{c}50 \\
\text { percentile }\end{array}$ & 26,500 & 6500 & 520 & & & & & & & 520 & -79.8 \\
\hline $\begin{array}{c}75 \\
\text { percentile }\end{array}$ & 49,800 & 29,800 & 800 & 2970 & & & & & & 3770 & -7.6 \\
\hline $\begin{array}{c}90 \\
\text { percentile }\end{array}$ & 83,000 & 63,000 & 800 & 4500 & 5750 & & & & & 11,050 & -10.8 \\
\hline $\begin{array}{c}95 \\
\text { percentile }\end{array}$ & 112,500 & 92,500 & 800 & 4500 & 10,000 & 6125 & & & & 21,425 & 6 \\
\hline $\begin{array}{c}99 \\
\text { percentile }\end{array}$ & 210,000 & 190,000 & 800 & 4500 & 10,000 & 24,500 & 16,000 & & & 55,800 & 15 \\
\hline $\begin{array}{c}99.5 \\
\text { percentile }\end{array}$ & 450,000 & 430,000 & 800 & 4500 & 10,000 & 24,500 & 60,000 & 45,000 & 15,000 & 159,800 & 19.3 \\
\hline Тор 0.2\% & $5,000,000$ & $4,980,000$ & 800 & 4500 & 15,000 & 24,500 & 60,000 & 45,000 & $2,290,000$ & $2,439,800$ & 25.1 \\
\hline
\end{tabular}

and a proposed tax structure. Under the alternative tax structure, tax bands are widened and marginal tax rates are revised so that the top marginal tax rate stands at $50 \%$ and applies to taxable incomes over $\$ 400,000$. It can be seen that those with annual incomes up to $\$ 83,000$ will all experience a decline in tax, while those above this income will pay more, but even for those earning up to $\$ 210,000$ annual incomes not by much more. The proposed tax changes mean effectively only those with top 5\% incomes will pay more taxes, while $95 \%$ income earners will pay less. Considering that the share of incomes for the top $1 \%$ earners is about $20 \%$, while the median income earner makes only about $\$ 26,000$, who pay very little tax any way, the sacrifice of tax revenues for reducing taxes for the low incomes is relatively small.

One objection against raising the progressivity of the personal income tax is that the super-rich could migrate, and then the tax base could erode. Eduardo Saverin, the billionaire co-founder of Facebook, renounced his U.S. citizenship and moved to Singapore for tax reasons, and he was not alone. Some jurisdictions also actively seek 
to offer citizenship to the very rich. For example, Russian President Vladimir Putin granted citizenship to Gerard Depardieu, the French movie star who wanted to avoid a tax hike proposed by French President Francois Hollande.

There are three answers to this objection. First, the tax system, even with increasing progressivity and very high marginal tax rates, would still leave the super-rich extremely rich, since only incomes above very high levels will be subject to very high marginal tax rates. Second, while tax harmonization is indeed desirable if achievable, there will be no loss of economic efficiency even when such high income earners migrate to lower tax countries. Migration of taxpaying individuals will not affect either the location or the amount of business investment, which will still be promoted by the abolition of the profits tax, since it will still be in the interest of the firms' decision makers to maximize profits. Finally, considerations like personal networks, safety, cultural environment, personal attachment, and the quality of government, also carry great weight as regards whether a person would migrate. To the extent that some super-rich move away, prices for luxury homes may fall increasing attraction to other rich people. We may conclude that unless tax rates are exorbitant, such migrations are not very likely.

While a tax-induced change of the residence of persons does not affect efficiency, a tax-induced change of the location of corporations do. A recent letter to the editor at Financial Times from George Osborne, Pierre Moscovici and Wolfgang Schäuble, the ministers of finance for UK, France, and Germany respectively submitted that "the international corporate tax system is increasingly outdated" and "has allowed some large multinational companies to avoid paying their fair share in tax." They noted that "International tax standards have struggled to keep pace with our changing economy [17]. This has allowed some multinational companies to restructure their business to minimise the amount of tax they pay, shifting the taxation of their profits away from the jurisdictions where they are being generated, so that they pay less tax than smaller, less international companies.” An example is the tax avoidance tactics used by Apple Inc. ${ }^{16}$ According to Tim Cook the CEO of Apple Inc., this tax avoidance helped promote American employment and productivity, ${ }^{17}$ even though the tactic does have an effect on the organization of the activities of the corporation.

All this underscores the huge social costs and the ineffectiveness of the tax effort on the profits tax. The joint letter from the finance ministers cited an OECD report (2013) [18] Addressing Base Erosion and Profit Shifting to note that "the practices that some multinational enterprises use to reduce their tax liabilities have become more aggressive over the past decade. Some multinationals are exploiting the transfer pricing or treaty rules to shift profits to places with no or low taxation, allowing them to pay as little as 5 percent in corporate taxes while smaller businesses are paying up to 30 percent. This distorts competition, giving larger companies an advantage over smaller, more domestic companies.” The ministers vowed to take concerted action to ensure a competitive tax system that supports businesses, but where everyone pays their fair share. But this is going to increase enforcement costs, compliance costs, and may lead to other distortions.

\section{Taxing Personal Income versus Taxing Consumption}

Traditionally, economists tend to favor consumption tax over income tax because an income tax that does not exempt returns from investment may represent taxing effort twice-when it is first earned, and when earnings are generated from savings invested. In other words, an income tax taxes both savings and consumption. The traditional objection against taxing consumption is that if it is levied as a retail sales tax or a VAT it is regressive. This objection can be ameliorated by offering a tax refund that represents tax paid on basic consumption. However, one could still criticize the consumption tax as not being progressive. Bradford argued that a tax on consumption could still be progressive, and that a consumption tax does not have to be paid at the retail level. Thus workers with earnings below the exemption amount would pay no tax, while the highest earners would pay the highest tax rate, while workers with intermediate wages would face intermediate tax rates [19]. Caroll and Viard tried to spell out in greater detail how it could be implemented in the American context [20].

\footnotetext{
${ }^{16}$ This leading IT company has five subsidiaries in Ireland. Of these only two pay Irish profits tax. The other three do not pay any tax at all, because Ireland levies tax based on the location of the management and operations. A subsidiary such as Apple Operations International is registered in Ireland but there are no operations in Ireland; so it does not have to pay taxes. On the other hand America levies taxes based on the location of the incorporation of the company. Since the company is not incorporated on American soil, the IRS cannot levy tax on this subsidiary, which however had booked a profit of 20 billion dollars from 2009 to 2012 . The subsidiary merely collects the dividend payouts from Apple operations elsewhere.

${ }^{17}$ http://www.bloomberg.com/news/2013-05-21/apple-ceo-cook-rebuts-9-billion-tax-avoidance-claim.html
} 
The main objection is that this "consumption tax" is essentially a tax on labor income minus savings that are invested. Burmen expresses worry about the potential accumulation of enormous largely tax-exempt fortunes in family dynasties and says that he would be "more supportive of the proposal if it included large inheritances in the tax base.” [21] In any case consumption is such a tiny fraction of the incomes of the super-rich, to achieve any reasonable degree of progression through a progressive consumption tax will be very difficult in practice.

If the focus is on taxing personal incomes from all sources, it may be thought that there should be no need to tax both income and consumption. The case for taxing consumption in addition to incomes is that taxing incomes alone may miss all the incomes earned in the underground economy, and may end up disproportionately encouraging activities to go underground. Taxing both consumption and incomes will allow tax rates to be lower, especially for the ordinary people, and lower tax rates will minimize distortions on incentives.

To reiterate, since the incomes that some individuals earn are much higher than what they can spend, a tax on consumption alone cannot effectively tax the economic rents that they collect. This is not to deny the value of a tax targeted at consumption. A consumption tax will help recover taxes that otherwise would be lost as a result of incomes not reported. The conclusion then is that both incomes and consumption should be taxed. But just as there should be personal exemption for taxes on incomes, so there should be a tax refund for consumption taxes paid on basic spending. ${ }^{18}$

\section{Conclusions}

A recent OECD study concludes that "profits taxes are the most harmful type of tax for economic growth, followed by personal income taxes and then consumption taxes, with recurrent taxes on immovable property being the least harmful." [22] We have cited several works that support the abolition of the profits tax. Our analysis further shows that by effectively lowering marginal tax rates over the income range where "rent intensity" is low and raising marginal tax rates over the income range where rent intensity is high, the harmful effects of personal income taxes can be minimized. In addition, corrective taxes on environmental disruption, diamond goods, relative competition/conspicuous consumption are even less harmful or efficiency-improving than taxes on immovable property.

Whereas Chetty and Saez [1] argued that their agency model suggests that cutting dividend tax would have a stronger positive effect on the quality of investment than cutting the profit tax, we argue that they had ignored the effect of the profit tax on the return from the effort expended on productive investment. Indeed, a paper that Chetty and Saez cited, namely Desai and Goolsbee [3] noted that President Bush's generous dividend tax cut, which had cost an estimated \$100 billion from 2003-2008, had little, if any, impact on investment. Independently compiled utilization/cyclically adjusted total factor productivity also did not display any improvement subsequent to the dividend tax cut. On the other hand, Desai and Goolsbee [3] found that the partial expensing of equipment provisions, at a revenue cost of approximately $\$ 130$ billion from 2002-2004, did have a small effect on investment. Positive or negative should be given.

The proposal to tax corporate profits at zero rate and to maintain a progressive personal income tax system can be seen as a variant of the "dual income tax" system pioneered by the Nordic countries and discussed in Bird and Zolt [23]. To Bird and Zolt, the dual income tax systems in Finland, Norway, and Sweden "provide for a progressive income tax rate schedule applicable to labor income and a flat tax rate on capital income” (p. 185). They further note that among these countries, the "highest marginal tax rate on labor income is about $15 \%-25 \%$ higher than the tax rate on capital income." Our proposal deviates from this model in arguing that personal incomes from all sources should be treated alike and should be subject to increasingly progressive tax rates, which will automatically tax rent-intensive incomes at higher marginal rates given that a higher intensity of economic rent tends to characterize successive increases in incomes.

Our proposal of widening tax bands and increasing tax progressivity is congruent with Piketty's suggestion that the top marginal tax rates should be raised to much higher levels than is the case in America [24]. His argument is that only this way can the widening income inequality that comes with globalization be redressed. The argument presented in this paper is that widening tax bands and raising tax progressivity makes the tax system

\footnotetext{
${ }^{18}$ One might ask why not just do not tax basic spending instead of refund. Earmarking particular items as basic spending is arbitrary and costly. For example there is a range of prices for beef. It is certainly arbitrary to determine above what unit price beef becomes not basic. A refund reflects what is paid on, say, 15,000 dollars of basic spending in retail level tax; there is no need to look at individual items of spending. The effect of the refund option is similar to making the income/transfer system more progressive, and it also makes the consumption tax more acceptable politically.
} 
more efficient, because incomes beyond some very high level tends to be more rent-intensive.

Abolishing the profits tax will simplify the tax system significantly and will enhance investment incentives by firms. As long as profits are reinvested, capital gains will be created in the shares of the companies, offering an alternative tax base that is clean and non-distortionary. If dividends are paid out to persons, personal incomes will be boosted, and they will be taxed at the applicable marginal tax rates. Taxing dividend incomes that accrue to persons should not be difficult because dividend payouts are all registered. Dividends paid to other corporations will not be taxed. The gradualist proposal of halving the profit tax and taxing only half of dividends and capital gains according to the tax rate structure seems to be a worthwhile intermediate step before scrapping the profit tax altogether. Retaining a sales or consumption tax will help lower the tax rates on incomes, further boost savings, and allow earnings in the underground economy to be taxed. Such a tax will be complemented by an annual refund for each citizen that effectively exempt spending for maintaining a basic living standard or even a progressive consumption tax structure [20] [21] [25].

Finally, it should be noted that taxes may distort decisions in efficient ways. Corrective environmental taxes are particularly timely given the threat on climate change caused by the emission of $\mathrm{CO}_{2}$ and other greenhouse gases. There are also the issues of conspicuous consumption and relative competition. Although the earliest analysis has been commonly attributed to Veblen 1899 [26], Rae (1834) [27] analysed the issue much earlier. More importantly, recent studies indicate that the problems are much more extensive and severe than most people think. Research shows that even poor peasants in rural areas in China and India regard the relative effects as about twice as important as the absolute effects (Fontaine \& Yamada 2012 [28], Guillen-Royo 2011 [29], Knight, Song \& Gunatilaka 2009 [30], Linssen, et al. [31], Wilkinson [32]). If we can identify goods with higher degrees of conspicuous and relative-competition effects, taxes on them may be corrective and hence efficiencyimproving. There is also the case of so-called diamond goods, taxing which would generate no excess burden. Pure diamond goods are goods valued for their values instead of intrinsic consumption effects (Ng 1987) [33]. Although pure diamond goods may be relatively rare, mixed diamond goods are very prevalent and should be considered for higher taxation in a comprehensive tax review.

\section{Acknowledgements}

We thank Richard Bird, Richard Cullen, Avinash Dixit, Yew-kwang Ng, and John Taylor for comments on early versions of the paper.

\section{References}

[1] Chetty, R. and Saez, E. (2010) Dividend and Corporate Taxation in an Agency Model of the Firm. American Economic Journal: Economic Policy, 2, 1-31.

[2] Lawrence, S. (2012) How to Fix Costly and Unjust US Tax System. Financial Times, 16 December 2012.

[3] Desai, Mihir, A. and Goolsbee, A.D. (2004) Investment, Overhang, and Tax Policy. Brookings Papers on Economic Activity, 2, 285-338. http://dx.doi.org/10.1353/eca.2005.0004

[4] Devereaux, M. (2006) The Impact of Taxation on the Location of Capital, Firms and Profit: A Survey of Empirical Evidence, Paper Prepared for the European Tax Policy Forum Conference "The Impact of Corporation Taxes Across. Borders. http://www.sbs.ox.ac.uk/centres/tax/Documents/working_papers/WP0702dataappendix.pdf

[5] Hassett, Kevin A. and Glenn Hubbard, R. (1996) Tax Policy and Investment. NBER Working Paper 5683, National Bureau of Economic Research.

[6] Djankov, S., Ganser, T., McLiesh, C., Ramalho, R. and Shleifer, A. (2010) The Effect of Corporate Taxes on Investment and Entrepreneurship. American Economic Journal: Macroeconomics, 2, 31-64. http://dx.doi.org/10.1257/mac.2.3.31

[7] Fehr, H., Jokisch, S., Kambhampati, A. and Kotlikoff, L.J. (2013) Simulating the Elimination of the US Profits Tax. NBER Working Paper No. 19757.

[8] Baccini, L., Li, Q. and Mirkina, I. (2014) Corporate Tax Cuts and Foreign Direct Investment. Journal of Policy Analysis and Management, 33, 977-1006. http://dx.doi.org/10.1002/pam.21786

[9] Wei, S.J. (1997) Gradualism versus Big Bang: Speed and Sustainability of Reforms. The Canadian Journal of Economics, 30, 1234-1247. http://dx.doi.org/10.2307/136319

[10] Fernald, J. (2014) A Quarterly Utilization-Adjusted Series on Total Factor Productivity. Federal Reserve Bank of San Francisco Working Paper. 
[11] Bartlett, B. (2013) The Bush Tax-Cut Failure. New York Times. http://economix.blogs.nytimes.com/2013/05/21/the-bush-tax-cut-failure/?_r=0

[12] Bargain, O., Kristian, O. and Andreas, P. (2011) Labor Supply Elasticities in Europe and the US. IZA Discussion Paper No. 5820.

[13] Mastrogiacomo, M., Bosch, N.M., Gielen, M.D. and Jongen, E.L. (2013) A Structural Analysis of Labor Supply Elasticities in the Netherlands. CPB Discussion Paper \#235, CPB Netherlands Bureau for Economic Policy Analysis.

[14] Rosen, S. (1981) The Economics of Superstars. American Economic Review, 71, 845-858.

[15] Borghans, L. and Groot, L. (1998) Superstardom and Monopolistic Power: Why Media Stars Earn More than Their Marginal Contribution to Welfare. Journal of Institutional and Theoretical Economics, 154, 546-571.

[16] Hamlen, S., Hamlen, W. and Southwick, L. (2013) A Model of Progressive Employee Compensation and Superstardom. Theoretical Economics Letters, 3, 1-6. http://dx.doi.org/10.4236/tel.2013.33A001

[17] Osborne, G., Moscovici, P. and Schäuble, W. (2013) We Are Determined That Multinationals Will Not Avoid Tax. Financial Times.

[18] OECD (2013) Addressing Base Erosion and Profit Shifting. OECD Publishing.

[19] Bradford, D.F. (1986) Untangling the Income Tax. Harvard University Press, Cambridge, 81-82, 329-334. http://dx.doi.org/10.4159/harvard.9780674733930

[20] Carroll, B. and Viard, A. (2012) Progressive Consumption Taxation: The X Tax Revisited. American Enterprise Institute.

[21] Burman, L. (2012) A Progressive Consumption Tax? Forbes Magazine. http://www.forbes.com/sites/leonardburman/2012/06/04/a-progressive-consumption-tax/\#35d6deb316d4

[22] OECD (2010) Tax Policy Reform and Economic Growth. http://www.oecd-ilibrary.org/taxation/tax-policy-reform-and-economic-growth_9789264091085-en November3

[23] Bird, R.M. and Zolt, E.M. (2010) Dual Income Taxation and Developing Countries. Columbia Journal of Tax Law, 1, 174-217.

[24] Piketty, T. (2014) Capital in the Twenty-First Century. Harvard University Press, Cambridge.

[25] Viard, A.D., Carroll, R. and Ganz, S. (2008) The X Tax: The Progressive Consumption Tax America Needs? Tax Policy Outlook, No. 4, American Enterprise Institute for Public Policy Research. http://www.aei.org/outlook/economics/fiscal-policy/the-x-tax-the-progressive-consumption-tax-america-needs/

[26] Veblen, T. (1899) The Theory of the Leisure Class. Macmillan, New York.

[27] Rae, J. (1834) New Principles of Political Economy. Reprinted as The Sociological Theory of Capital: Being a Complete Reprint of the News Principles of Political Economy, The Macmillan Company.

[28] Fontaine, X. and Yamada, K. (2012) Economic Comparison and Group Identity: Lessons from India.

[29] Guillen-Royo, M. (2011) Reference Group Consumption and the Subjective Wellbeing of the Poor in Peru. Journal of Economic Psychology, 32, 259-272. http://dx.doi.org/10.1016/j.joep.2009.12.001

[30] Knight, J., Song, L. and Gunatilaka, R. (2009) Subjective Well-Being and Its Determinants in Rural China. China Economic Review, 20, 635-649. http://dx.doi.org/10.1016/j.chieco.2008.09.003

[31] Linssen, R., van Kempen, L. and Kraaykampt, G. (2011) Subjective Well-Being in Rural India: The Curse of Conspicuous Consumption. Social Indicators Research, 101, 57-72. http://dx.doi.org/10.1007/s11205-010-9635-2

[32] Wilkinson, R.G. (1997) Health Inequalities: Relative or Absolute Material Standards? British Medical Journal, 314, 591-595. http://dx.doi.org/10.1136/bmj.314.7080.591

[33] Ng, Y.-K. (1987) Diamonds Are a Government’s Best Friend: Burden-Free Taxes on Goods Valued for Their Values. American Economic Review, 77, 186-191. 


\section{Appendix}

\section{A Formal Model to Show Profit Tax Reduces Investment}

In the following, we adopt the model employed in Chetty and Saez [1] (hereafter CS) but add the assumption that investment requires personal effort by the manager such that the effort is not observable and thus non-contractible. We aim to show two results. First, an increase in corporate tax will reduce the level of investment. This point is under-emphasized in the CS model. Second, as a consequence, the welfare loss is under-estimated in CS model.

To start with, we consider the two-period agency model that is similar to the one in CS (section A in part II). A firm has initial cash holding of $X$ at the beginning of period 0 . The manager of the firm chooses the allocation of the cash among paying out dividends, investing in a productive project, and investing in the manager's personal pet project. The allocated amounts are denoted as $D, I$ and $J$, respectively, with $D+I+J=X$. As in CS, we assume that the pet project only generates private benefit to the manager, $g(J)$, with $g^{\prime}>0$ and $g^{\prime \prime}<0$, but zero monetary benefit to the firm in period 1 . The productive project will yield an expected return of $f(I)$, with $f^{\prime}>0$ and $f^{\prime \prime}<0$, to the firm in period 1 . The firm is assumed to be wound up at the end of period 1 with net-of-tax profits and principal returned to shareholders. In contrast to CS, the manager in the refitted model has to incur some positive personal effort to start and to manage the productive project. In particular, we assume that the individual effort spent by the manager is $e(I)$ with $e^{\prime} \geq 0$ and $e^{\prime \prime} \geq 0$, reflecting the fact that as investment increases, generally the complexity of investment will rise demanding a disproportionate increase in effort. Because potential loss also rises, the manager is expected to bear more pressures. Two types of taxes are applicable to the firm's profits: a corporate tax at rate $t_{c}$ that is imposed on the firm's net profit and a dividend tax at rate $t_{d}$ that is placed on distributed dividends. The interest rate is denoted as $r$.

In this agency model, the shareholders of the firm have to rely on the manager to make investment. Thus, there is an incentive problem because the pet project generates private benefit while the productive project calls for costly efforts. To alleviate the incentive problem, the shareholders can provide incentive pay and monitor the manager to reduce investment in the pet project. We assume that the shareholders compensate the manger with $\alpha$ shares (in percentage) of company to provide managerial incentive and that the shareholders spend effort $\gamma$ in monitoring the manager which leads to a reduction of the benefits of the pet project which then becomes $g(J) /(1+\gamma)$.

The manager chooses $D, I$ and $J$ to maximize, subject to $D+I+J=X$,

$$
V^{M}=\omega\left[D+\frac{\left(1-t_{c}\right) f(I)+X-D}{1+r}\right]+\frac{g(X-I-D)}{1+r}-e(I)
$$

where $\omega=\alpha\left(1-t_{d}\right)(1+\gamma)$ is the manager's weight on profit as defined in CS (page 11, section B). Hence, the optimal choices of $D$ and $I$ satisfy the first-order conditions,

$$
\omega\left(1-t_{c}\right) f^{\prime}(I)=g^{\prime}(X-I-D)+(1+r) e^{\prime}(I)
$$

and

$$
\omega r \leq g^{\prime}(X-I-D) \text { with strict equality if and only if } D>0 .
$$

We next discuss the effect of corporate tax on the investment of productive project. Consider first the case where $D=0$. In this case, $I^{*}$ is determined by (1). Total differentiation of (1) with respect to $t_{c}$ is

$$
-\omega f^{\prime}(I)+\omega\left(1-t_{c}\right) f^{\prime \prime}(I) \frac{\partial I}{\partial t_{c}}=-g^{\prime \prime}(X-I) \frac{\partial I}{\partial t_{c}}+(1+r) e^{\prime \prime}(I) \frac{\partial I}{\partial t_{c}}
$$

or

$$
\frac{\partial I}{\partial t_{c}}=\frac{\omega f^{\prime}(I)}{\omega\left(1-t_{c}\right) f^{\prime \prime}(I)+g^{\prime \prime}(X-I)-(1+r) e^{\prime \prime}(I)} .
$$

Since $f^{\prime}>0, f^{\prime \prime}<0, g^{\prime \prime}<0$ and $e^{\prime \prime}>0$, it follows that $\frac{\partial I}{\partial t_{c}}<0$.

We next consider the case where $D>0$. In this case, $I^{*}$ is jointly determined by (1) and (2) with equality. 
Substituting $g^{\prime}(X-I-D)$, we have

$$
\omega\left(1-t_{c}\right) f^{\prime}(I)=\omega r+(1+r) e^{\prime}(I) .
$$

Total differentiation of the above equation with respect to $t_{c}$ yields

$$
-\omega f^{\prime}(I)+\omega\left(1-t_{c}\right) f^{\prime \prime}(I) \frac{\partial I}{\partial t_{c}}=(1+r) e^{\prime \prime}(I) \frac{\partial I}{\partial t_{c}}
$$

which implies

$$
\frac{\partial I}{\partial t_{c}}=\frac{\omega f^{\prime}(I)}{\omega\left(1-t_{c}\right) f^{\prime \prime}(I)-(1+r) e^{\prime \prime}(I)} .
$$

Again, we have $\frac{\partial I}{\partial t_{c}}<0$ in this case.

Thus, we have shown that an increase in corporate tax reduces investment effort. Note that in both cases, $\frac{\partial I}{\partial t_{c}}<0$ holds even in the extreme case where the manager does not incur effort in productive project. Moreover, $\frac{\partial I}{\partial t_{c}}$, which is negative, is smaller when $e^{\prime \prime}>0$ than when $e^{\prime \prime}=0$, meaning that the negative effect on investment is more prominent in our model with positive personal effort for productive project.

We next consider the impact on total welfare. To illustrate, in the most transparent way, the point that the welfare loss is under-estimated in CS model in which personal effort by manager is absent, we follow CS, in particular section IV (A), to consider the case of fixed contracts where $\gamma$ is fixed at 0 . In this case, the total surplus in the economy $(W)$ is simply the sum of shareholders' payoff, the manager's payoff, and government revenue from dividends and corporate taxes:

$$
\begin{aligned}
W= & V^{M}+V^{S}+t_{d} P_{d}(\omega)+t_{c} P_{c}(\omega) \\
= & \alpha\left(1-t_{d}\right)\left[D+\frac{\left(1-t_{c}\right) f(I)+X-D}{1+r}\right]+\frac{g(J)}{1+r} \\
& -e(I)+(1-\alpha)\left(1-t_{d}\right) P_{d}(\omega)+t_{c} P_{c}(\omega)
\end{aligned}
$$

where we denote $P_{d}=D+\left[\left(1-t_{c}\right) f(I)+X-D\right] /(1+r)$ and $P_{c}=f(I) /(1+r)$ as the dividend and corporate tax bases, respectively.

Noticing that the manager chooses $D$ and $I$ to maximize $V^{M}$, we have, by the envelope conditions,

$$
\frac{\mathrm{d} W}{\mathrm{~d} t_{d}}=t_{c} \frac{\mathrm{d} P_{c}}{\mathrm{~d} t_{d}}+t_{d} \frac{\mathrm{d} P_{d}}{\mathrm{~d} t_{d}}+\left(1-t_{d}\right)(1-\alpha) \frac{\mathrm{d} P_{d}}{\mathrm{~d} t_{d}}
$$

and

$$
\frac{\mathrm{d} W}{\mathrm{~d} t_{c}}=t_{c} \frac{\mathrm{d} P_{c}}{\mathrm{~d} t_{c}}+t_{d}\left(\frac{\mathrm{d} P_{d}}{\mathrm{~d} t_{c}}-\frac{\partial P_{d}}{\partial t_{c}}\right)+\left(1-t_{d}\right)(1-\alpha)\left(\frac{\mathrm{d} P_{d}}{\mathrm{~d} t_{c}}-\frac{\partial P_{d}}{\partial t_{c}}\right)
$$

where $\partial P_{d} / \partial t_{c}=-P_{c}$ is the mechanical effect of increasing $t_{c}$ on the firm's payout (CS, page 21). Note that

$$
\frac{\mathrm{d} P_{d}}{\mathrm{~d} t_{c}}=-P_{c}-\left(\frac{r}{1+r}\right) \frac{\partial J}{\partial t_{c}}=-P_{c}-\left(\frac{r}{1+r}\right) \frac{\partial I}{\partial t_{c}}<\frac{\partial P_{d}}{\partial t_{c}}
$$

since $\frac{\partial I}{\partial t_{c}}<0$. It follows that

$$
\frac{\mathrm{d} W}{\mathrm{~d} t_{d}}=\left[t_{d}+\left(1-t_{d}\right)(1-\alpha)\right] \frac{\mathrm{d} P_{d}}{\mathrm{~d} t_{d}}
$$

and 


$$
\frac{\mathrm{d} W}{\mathrm{~d} t_{c}}=t_{c} \frac{\mathrm{d} P_{c}}{\mathrm{~d} t_{c}}+\left[t_{d}+\left(1-t_{d}\right)(1-\alpha)\right]\left(\frac{r}{1+r}\right) \frac{\partial I}{\partial t_{c}} .
$$

Comparing (3) and (4) with the results in CS (their equations 25 and 26), which are

$$
\frac{\mathrm{d} W}{\mathrm{~d} t_{d}}=\left[t_{d}+\left(1-t_{d}\right)(1-\alpha)\right] \frac{\mathrm{d} P_{d}}{\mathrm{~d} t_{d}}
$$

and

$$
\frac{\mathrm{d} W}{\mathrm{~d} t_{c}}=t_{c} \frac{\mathrm{d} P_{c}}{\mathrm{~d} t_{c}}
$$

we find that an additional (negative) term appears in (4). Thus, in the absence of investment effort by manager, CS is likely to underestimate the distortion of corporate taxes.

\section{Submit or recommend next manuscript to SCIRP and we will provide best service for you:}

Accepting pre-submission inquiries through Email, Facebook, LinkedIn, Twitter, etc.

A wide selection of journals (inclusive of 9 subjects, more than 200 journals)

Providing 24-hour high-quality service

User-friendly online submission system

Fair and swift peer-review system

Efficient typesetting and proofreading procedure

Display of the result of downloads and visits, as well as the number of cited articles

Maximum dissemination of your research work

Submit your manuscript at: http://papersubmission.scirp.org/ 